\title{
Effects of Low Dietary Calcium on the Dynamic State of Bone Mobilization along with Shell Formation
}

\author{
Emiko Watanabe, Akio Annaka and Teru Ishibashi \\ Graduate School of Science and Technology, \\ Niigata University, Niigata-shi, 950-21
}

To elucidate the dynamic state of bone mobilization along with the egg shell formation cycle, the effects of low calcium (Ca) diets on the fluctuations of the $\mathrm{Ca}$ and phosphorus (P) excretion were studied. Laying hens were fed a control diet containing $2.9 \% \mathrm{Ca}$ for 7 days and then divided into two groups and fed low $\mathrm{Ca}$ diets $(1.38 \%$ or $0.26 \% \mathrm{Ca})$ for 2 days. These experimental diets contained chromic oxide $\left(\mathrm{Cr}_{2} \mathrm{O}_{3}\right)$ as an indicator. The excreta was collected every $3 \mathrm{~h}$ on the 7 th day after feeding the control diet and for 2 days following switching to the low $\mathrm{Ca}$ diets.

The continuous excretion of $\mathrm{Cr}_{2} \mathrm{O}_{3}$ was observed even during the dark period. This indicates that the food consumed before dark was maintained in the crop and gradually moved into the lower digestive tract during dark period. When hens were fed the control diet, $\mathrm{Ca}$ retention did not decrease and $\mathrm{P}$ retention decreased during later shell formation. This indicates that the excretion of endogenous $\mathrm{P}$ increased, because $\mathrm{P}$ consumption was constant and $\mathrm{P}$ excretion increased during this period.

After switching to the low $\mathrm{Ca}$ diets, the eggshell weights and $\mathrm{Ca}$ contents decreased and $\mathrm{Ca}$ and $\mathrm{P}$ balances were negative. $\mathrm{P}$ retention decreased and the time when it began to decrease was hastened by feeding the lower Ca diet. This indicates that dietary $\mathrm{Ca}$ deficiency increase the amount of bone mobilization during shell formation and that of the excretion of endogenous $P$.

These results suggest that the contribution of bone $\mathrm{Ca}$ for shell $\mathrm{Ca}$ changed along with the change of the balance between dietary $\mathrm{Ca}$ intake and the demand for shell $\mathrm{Ca}$.

(Jpn. Poult. Sci., 29 : 277-286, 1992)

Key words : retention of $\mathrm{P}$, retention of $\mathrm{Ca}$, bone mobilization, low $\mathrm{Ca}$ diet, egg formation cycle

\section{Introduction}

It is generally accepted that the contribution of bone $\mathrm{Ca}$ as well as dietary $\mathrm{Ca}$ to shell calcification is very important. IsHiBASH et al. (1986) proved that hens fed ${ }^{45} \mathrm{Ca}$ before shell calcification quickly stored $\mathrm{Ca}$ in the bone and then deposited it on the shell as 'temporary bone Ca'. However, the quantitative relationship of Ca derived from these two sources has not been established in spite of so many publications (Mueller et al., 1964 ; Itoh, 1967 ; Hurwitz and BAR, 1969 ; FArmer et al., 1986). Ітон (1967) suggests that about $90 \%$ of egg shell $\mathrm{Ca}$ is derived from the bone. On the other hand, FARMER et al. (1986) repored that only $28 \%$ of the total egg shell Ca was derived from bone in the hens fed an adequate $\mathrm{Ca}$ diet. Although ${ }^{45} \mathrm{Ca}$ was used as an 
indicator of $\mathrm{Ca}$ dynamics in both studies, the discrepancy may be caused by how long or when ${ }^{45} \mathrm{Ca}$ was administered to the hens. The extent of bone Ca contribution itself may not be constant and may change along with shell calcification.

Urinary $\mathrm{P}$ is one of indicators of bone mobilization, because $\mathrm{P}$ is derived from bone with Ca. Wideman (1967) showed that the amounts of P in excreta fluctuated along with egg cycle. CHOI et al. (1970) indicated that most of the increased P in excreta during shell formation was the endogenous $\mathrm{P}$ derived from bone with Ca. If dietary $\mathrm{Ca}$ is deficient, the endogenous $\mathrm{P}$ excretion should increase or fluctuate greatly, because bone mobilization should increase for supplying shell Ca.

The purpose of this study was to elucidate the relationship between dietary $\mathrm{Ca}$ and bone $\mathrm{Ca}$ used for shell calcification. The hens were fed low Ca diets to emphasize a deficiency of $\mathrm{Ca}$ to evoke the mobilization of $\mathrm{Ca}$ from the bone.

\section{Materials and Methods}

Thirty hens 35 (Shaver Starcross-288 strain) weeks old at a high egg production rate were housed in individual wire cages in a room with a $16 \mathrm{~h}$ light schedule (4:00-20:00). All hens were fed the control diet (2.9\% of $\mathrm{Ca})$ and water ad libitum for 7 days. On the oviposition time of the 7 th day, they were subjected to switch either one of the two levels of low $\mathrm{Ca} \operatorname{diet}(1.38 \%$ or $0.26 \%$ of $\mathrm{Ca}$ ), as shown in Table 1. $\mathrm{Cr}_{2} \mathrm{O}_{3}$ was added at a $0.1 \%$ level as an internal indicator for calculation of the intake of $\mathrm{Ca}$ and $\mathrm{P}$ from those in the excreta. The control diet was switched to the low Ca diets at the oviposition time of each hen.

On the fifth day of feeding a control diet, hens with oviposition between 6:00 and 10:00 (first oviposition) were used for the experiment. At switching to the low Ca diets, the hens were allocated to two groups at the oviposition. All excreta were collected every $3 \mathrm{~h}$ on the last day on the control diet and for 2 consecutive days on the experimental diets. These samples were stored at $-20^{\circ} \mathrm{C}$. At each collection time, feed consumption was recorded. Eggs were collected on these 3 consecutive days. In the case that hens did not lay consecutively for these 3 days, the hens were excepted. After removing the egg yolk and white, the eggshell with shell membrane was washed with water and dried at $100^{\circ} \mathrm{C}$ for $3 \mathrm{~h}$. After weighing the dry matter of the egg shell with the shell membrane, it was ground for analysis of Ca.

The stored excreta were thawed and homogenized with an ultrasonic wave mixer (Ikeda Rika Co. LTD., Tokyo). Aliquotes of them were applied for determination of $\mathrm{Cr}_{2} \mathrm{O}_{3}$, Ca and $\mathrm{P} . \mathrm{Cr}_{2} \mathrm{O}_{3}$ was determined spectrophotometrically by a procedure described by SunAhara et al. (1989). Ca was determined with an atomic absorption spectrophotometry (Hitachi Atomic Absorption Spectrophotometry, Hitachi Seisakusho

Inc., Tokyo). $\mathrm{P}$ was determined by spectrophotometry as phosphomolybdate (СноI et al., 1970).

The amount of nutrient consumed corresponding to the amount of excreta collected for each period was calculated by the following formula described by $\mathrm{CHOI}$ et al. (1979) :

Amount of nutrient consumed $(\mathrm{mg} / \mathrm{period})=$ 
Table 1. Composition of experimental diets (\%)

\begin{tabular}{lccc}
\hline \hline \multicolumn{1}{c}{ Ingredient } & Control & $1.38 \% \mathrm{Ca}$ & $0.26 \% \mathrm{Ca}$ \\
\hline Ground yellow com & 73.91 & 80.62 & 80.81 \\
Soybean meal & 13.00 & 12.00 & 13.00 \\
Fish meal & 2.00 & 2.00 & 2.00 \\
Soybean oil & 1.00 & 1.00 & 1.00 \\
Ground oyster shell & 7.50 & 1.80 & - \\
Dicalcium phosphate & 2.00 & 2.00 & - \\
$\mathrm{KH}_{2} \mathrm{HPO}_{4}$ & - & - & 2.47 \\
$\mathrm{Na}_{2} \mathrm{HPO}_{4}$ & - & - & 0.13 \\
Sodium chloride & 0.25 & 0.25 & 0.25 \\
Vitamin-Mineral Premix & & 0.06 & 0.06 \\
Choline chloride & 0.06 & 0.10 & 0.10 \\
Chromic oxide & 0.10 & 0.10 & 0.10 \\
DL-Methionine & 0.10 & 0.07 & 0.08 \\
Calculated analysis & 0.08 & & \\
Metabolizable enegy (kcal/kg) & & 3,135 & 3.165 \\
Crude protein & 2,934 & 13.9 & 14.4 \\
Lysine & 13.9 & 0.64 & 0.67 \\
Total sulfur amino acids & 0.65 & 0.55 & 0.58 \\
Ca & 0.55 & 1.38 & 0.26 \\
available P & 2.90 & 0.48 & 0.37 \\
Total P & 0.45 & 0.841 & 0.716 \\
\hline
\end{tabular}

${ }^{1}$ Vitamin-mineral premix supplied per $\mathrm{kg}$ of diet: vitamin A 4,000 IU; vitamin $\mathrm{D}_{3}$, $1,500 \mathrm{IU}$; vitamin $\mathrm{B}_{12}, 5 \mu \mathrm{g}$; riboflavin, $3.5 \mathrm{mg}$; calcium pantothenate, $6.0 \mathrm{mg}$; niacin, $22 \mathrm{mg}$; manganese, $20 \mathrm{mg}$; iodine, $23 \mathrm{mg}$.

$\left[\mathrm{Cr}_{2} \mathrm{O}_{3}(\mathrm{mg})\right.$ in excreta $\times$ nutrient $(\%)$ in diet $] /\left[\mathrm{Cr}_{2} \mathrm{O}_{3}(\%)\right.$ in feed $] \times 100 /$ recovery of $\mathrm{Cr}_{2} \mathrm{O}_{3}(\%)$.

where recovery of $\mathrm{Cr}_{2} \mathrm{O}_{3}(\%)$ was calculated one by one bird and day.

Percent recovery $=$

[amount of $\mathrm{Cr}_{2} \mathrm{O}_{3}$ excreted (mg/day)/amount of $\mathrm{Cr}_{2} \mathrm{O}_{3}$ intake $(\mathrm{mg} /$ day) $] \times 100$.

The effect of dietary $\mathrm{Ca}$ on the egg, eggshell and eggshell $\mathrm{Ca}$ weight was determined by one-way analysis of variance. Two-way analysis of variance was conducted for determination of the effects of sampling time and the dietary effects and these interactions on the amounts of $\mathrm{Ca}$ and $\mathrm{P}$ consumed, excreted and retained. Means were subjected to Duncan's multiple range test (1955). These analysis of variances and separation of means were conducted using the General Linear Models procedure of SAS (1986). The statistical significance was $\mathrm{P}<0.05$.

\section{Results}

Four birds from each group laid between 6:00 and 10:00 on the fifth day of feeding a control diet and they laid every day until the end of the 3 experimental days. The mean time of the egg formation cycle was $24.8 \pm 0.4 \mathrm{~h}$, and there was neither significant difference among dietary groups or dates of the experiment. As shown in Table 2, 
though egg weight did not decrease, shell weight decreased significantly after switching from the control diet to the low $\mathrm{Ca}$ diets. A lower dietary $\mathrm{Ca}$ intake resulted in a lower egg shell weight.

The effect of the dietary $\mathrm{Ca}$ level on the balances of $\mathrm{Ca}$ and $\mathrm{P}$ are shown in Table 3. The amount of consumed, excreted, and retained $\mathrm{Ca}$ decreased as the level of dietary $\mathrm{Ca}$ decreased, respectively. The amount of retained $\mathrm{Ca}$ of $1.38 \% \mathrm{Ca}$ group was

Table 2. Influence of dietary calcium level on egg and eggshell weights

\begin{tabular}{|c|c|c|c|c|}
\hline \multicolumn{2}{|c|}{ Treatment } & \multirow{2}{*}{$\begin{array}{l}\text { Number } \\
\text { of birds }\end{array}$} & \multirow{2}{*}{$\begin{array}{c}\text { Egg } \\
\text { weight } \\
\text { (g) }\end{array}$} & \multirow{2}{*}{$\begin{array}{l}\text { Shell } \\
\text { weight } \\
\text { (g) }\end{array}$} \\
\hline Diet & Day & & & \\
\hline \multirow{3}{*}{$\begin{array}{l}\text { Control } \\
1.38 \% \mathrm{Ca}\end{array}$} & & 8 & 61.6 & $6.1^{\mathrm{a}}$ \\
\hline & 1st day & 4 & 59.1 & 5. $6^{a b}$ \\
\hline & 2nd day & 4 & 59.8 & $5.5^{\mathrm{bc}}$ \\
\hline \multirow[t]{2}{*}{$0.26 \% \mathrm{Ca}$} & 1st day & 4 & 59.2 & $5.2^{\mathrm{c}}$ \\
\hline & 2nd day & 4 & 59.8 & $4.7^{\mathrm{d}}$ \\
\hline \multicolumn{2}{|c|}{ Means \pm SEM } & & $60.1 \pm 0.3$ & $5.7 \pm 0.1$ \\
\hline
\end{tabular}

Table 3. Consumption and excretion of calcium and phosphorus ${ }^{1}$

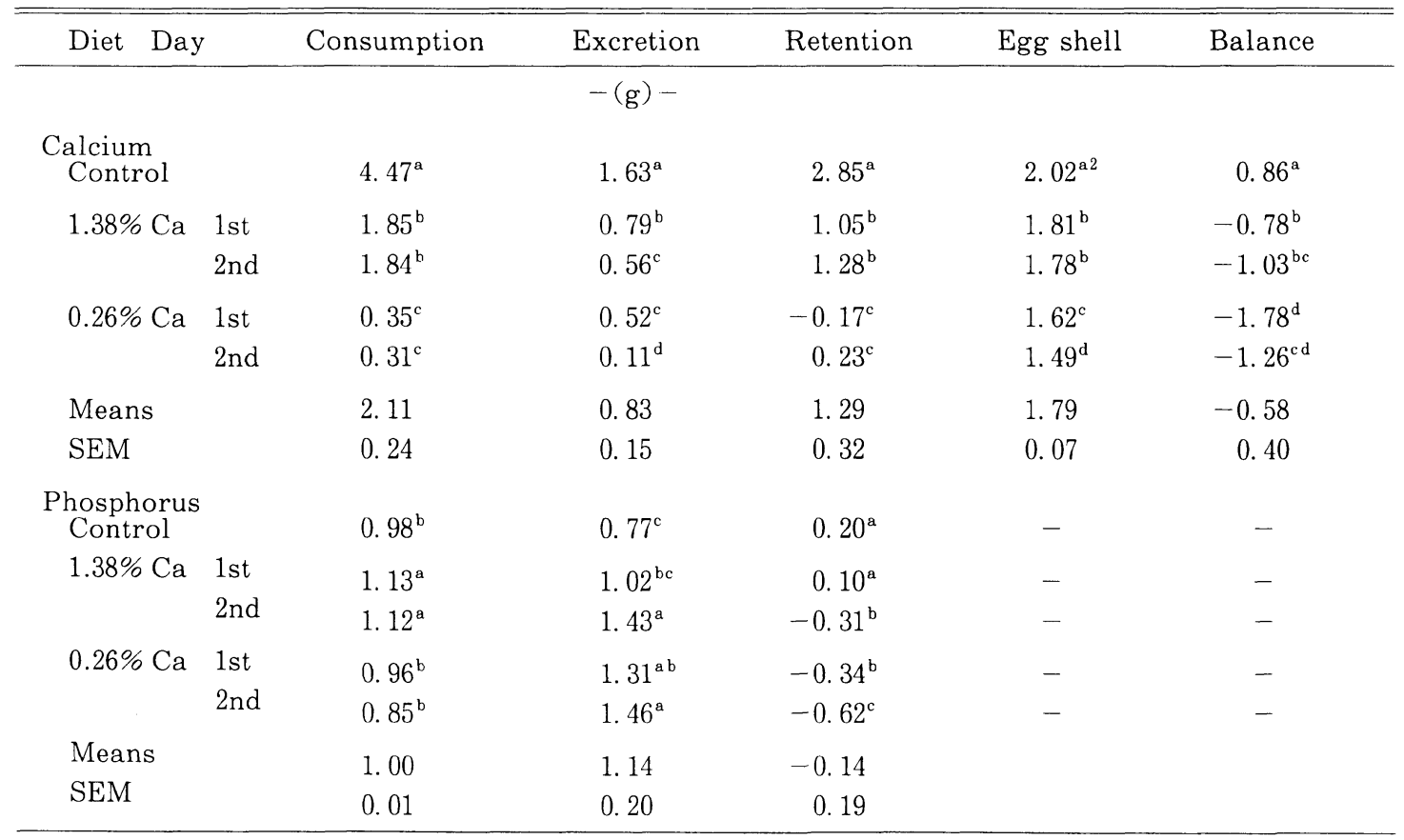

${ }^{1}$ The amount of $\mathrm{Ca}$ and $\mathrm{P}$ consumption and excretion were calculated from $\mathrm{Cr}_{2} \mathrm{O}_{3}$ in excreta during each egg cycle, as shown in materials and methods section.

${ }^{a-d}$ Means in the same column and mineral with different superscripts differ significantry $(\mathrm{P}<$ $0.05)$. 
$43 \%$, and that of $0.26 \% \mathrm{Ca}$ group was only $2 \%$ of the control group. The shell $\mathrm{Ca}$ weight also decreased after switching to the low Ca diets as dietary Ca level decreased. The shell $\mathrm{Ca}$ further decreased on the second day when hens fed the diet containing $0.26 \% \mathrm{Ca}$. The $\mathrm{Ca}$ balances of both low $\mathrm{Ca}$ diet groups were negative.

On the control group, $79 \%$ of $\mathrm{P}$ consumed was recovered in the excreta. The $\mathrm{P}$ recovered in the excreta increased after switching to the low Ca diets. When $0.26 \% \mathrm{Ca}$ was fed, the amount of $\mathrm{P}$ in the excreta reached $173 \%$ of consumed on the second day.

Average percent recovery of $\mathrm{Cr}_{2} \mathrm{O}_{3}$ was $87.4 \pm 3.5 \%$. The actually determined amount of feed consumption at each period and calculated amount of it from $\mathrm{Cr}_{2} \mathrm{O}_{3}$ in excreta at each period are shown in Fig. 1. During the dark period from 20:00 to 4:00, no feed was consumed, but the excretion of $\mathrm{Cr}_{2} \mathrm{O}_{3}$ continued. There was no significant effect of time on the fluctuation in the amount of $\mathrm{Cr}_{2} \mathrm{O}_{3}$ in the excreta during shell formation in each dietary treatment.

As shown in Table 4, when hens fed a control diet, the amount of $\mathrm{Ca}$ in excreta fluctuated with time passed after oviposition. The lesser amount of Ca was excreted during the periods between from 12 to $18 \mathrm{~h}$ after oviposition than the other periods. After switching from the control diet to both low Ca diets, the amount of Ca excreted markedly decreased until $18 \mathrm{~h}$ after oviposition and thereafter slightly increased. There was no significant fluctuation in Ca retention during shell formation when hens fed the control diet or the low Ca diet, except for during the early periods after switching to the both low Ca diets (Fig. 2).

The amount of $\mathrm{P}$ excreted on the control diet remained at a constant at $25 \mathrm{mg} / \mathrm{h}$ until $15 \mathrm{~h}$ and then increased two-fold until $24 \mathrm{~h}$ after oviposition as shown in Table 5. When hens fed low Ca diets, the amount of $\mathrm{P}$ excreted also remained constant level for a while after oviposition and thereafter increased. The time when the $\mathrm{P}$ excretion began to increase was earlier in the lower Ca diet group compared to the control diet

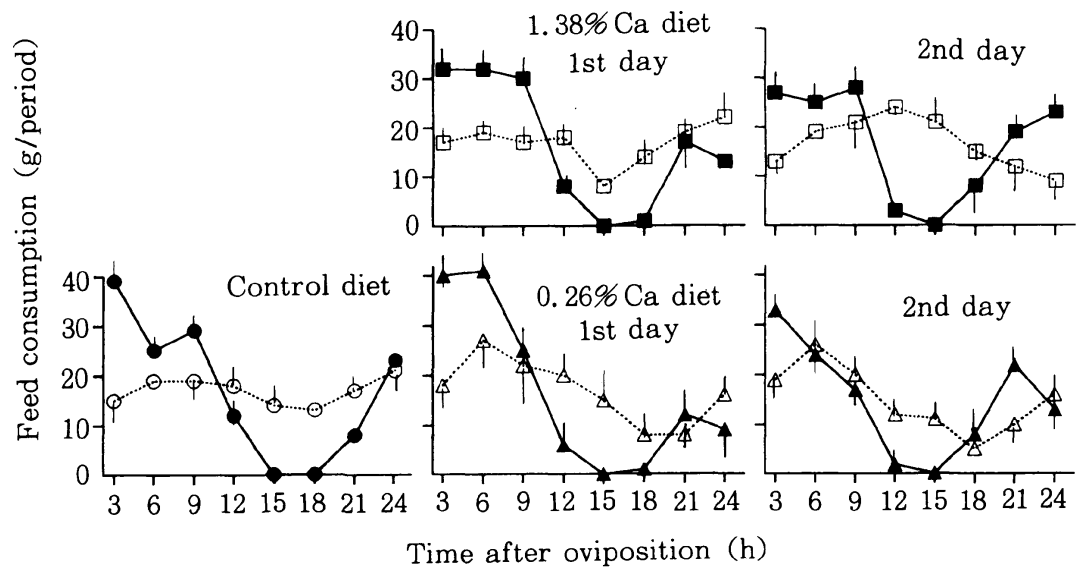

Fig. 1. Time course of feed consumption ( $, \mathbf{\square}, \mathbf{\Delta})$ and calculated feed consumption corresponding to the amount of excreted $\mathrm{Cr}_{2} \mathrm{O}_{3}(\bigcirc, \square, \triangle)$. Data are presented as the $\mathrm{X} \pm \mathrm{SEM}$. Control group $(\boldsymbol{\bullet}, \bigcirc) ; 1.38 \%$ Ca group $(\boldsymbol{\square}, \square)$; $0.26 \%$ Ca group $(\boldsymbol{\Delta}, \triangle)$. 
Table 4. Time course of consumption and excretion of calcium ${ }^{1}$

\begin{tabular}{|c|c|c|c|c|c|c|c|c|c|c|c|}
\hline \multirow{2}{*}{ Diet } & \multirow{2}{*}{ Day } & \multicolumn{8}{|c|}{ Collection period (h after oviposition) } & \multirow{2}{*}{ Mean } & \multirow{2}{*}{ SEN } \\
\hline & & $0-3$ & $3-6$ & $6-9$ & $9-12$ & $12-15$ & $15-18$ & $18-21$ & $21-24$ & & \\
\hline \multicolumn{12}{|c|}{$-(\mathrm{mg} /$ period $)-$} \\
\hline \multicolumn{2}{|c|}{$\begin{array}{l}\text { Consumption } \\
\text { Control }\end{array}$} & 485 & 633 & 612 & 602 & 476 & 432 & 557 & 680 & $560^{\mathrm{x}}$ & 28 \\
\hline \multirow[t]{2}{*}{$1.38 \% \mathrm{Ca}$} & 1 st & 215 & 242 & 236 & 258 & 123 & 177 & 256 & 339 & $231^{\mathrm{y}}$ & 20 \\
\hline & 2nd & 183 & 261 & 302 & 337 & 280 & 198 & 161 & 116 & $230^{y}$ & 14 \\
\hline \multirow{2}{*}{$0.26 \% \mathrm{Ca}$} & 1 st & 46 & 68 & 53 & 59 & 36 & 20 & 22 & 46 & $44^{2}$ & 3 \\
\hline & 2 nd & 48 & 69 & 51 & 30 & 27 & 14 & 26 & 44 & $39^{z}$ & 2 \\
\hline Mean & & 233 & 304 & 298 & 302 & 226 & 203 & 251 & 302 & & \\
\hline SEM & & 25 & 22 & 28 & 30 & 26 & 31 & 26 & 40 & & \\
\hline \multicolumn{2}{|l|}{$\begin{array}{r}\text { Excretion } \\
\text { Control }\end{array}$} & $203^{\mathrm{x}, \mathrm{bc}}$ & $263^{\mathrm{x}, \mathrm{ab}}$ & $239^{\mathrm{x}, \mathrm{abc}}$ & $191^{\mathrm{x}, \mathrm{c}}$ & $111^{x, d}$ & $119^{\mathrm{x}, \mathrm{d}}$ & $221^{\mathrm{x}, \mathrm{abc}}$ & $280^{\mathrm{x}, \mathrm{a}}$ & 203 & 7 \\
\hline \multirow[t]{2}{*}{$1.38 \% \mathrm{Ca}$} & $1 \mathrm{st}$ & $252^{\mathrm{x}, \mathrm{a}}$ & $155^{\mathrm{y}, \mathrm{b}}$ & $106^{y, b c}$ & $70^{y, c d}$ & $37^{y z, c d}$ & $27^{2, \mathrm{~d}}$ & $46^{\mathrm{yz}, \mathrm{cd}}$ & $101^{y, b c}$ & 99 & 8 \\
\hline & 2nd & $56^{y}$ & $76^{y}$ & $68^{\mathrm{yz}}$ & $54^{\mathrm{yz}}$ & $66^{\mathrm{y}}$ & $75^{y}$ & $75^{\mathrm{y}}$ & $88^{y z}$ & 70 & 9 \\
\hline \multirow[t]{2}{*}{$0.26 \% \mathrm{Ca}$} & 1st & $237^{\mathrm{x}, \mathrm{a}}$ & $159^{\mathrm{z}, \mathrm{b}}$ & $63^{\mathrm{yz}, \mathrm{c}}$ & $20^{y z, c}$ & $9^{z, c}$ & $8^{z, c}$ & $9^{z, c}$ & $10^{2, \mathrm{c}}$ & 64 & 8 \\
\hline & $2 \mathrm{nd}$ & $13^{\mathrm{y}, \mathrm{ab}}$ & $18^{z, a}$ & $14^{2, \mathrm{ab}}$ & $7^{2, \mathrm{c}}$ & $7^{2, \mathrm{c}}$ & $4^{2, c}$ & $5^{2, c}$ & $9^{2, b c}$ & 9 & 1 \\
\hline Mean & & 233 & 304 & 298 & 302 & 226 & 203 & 251 & 302 & & \\
\hline SEM & & 14 & 9 & 8 & 8 & 6 & 6 & 8 & 1 & & \\
\hline
\end{tabular}

ANOVA, significance

$\begin{array}{llcc} & \text { Dietary effect } & \text { Time effect } & \text { Interaction } \\ \text { Consumption } & <0.0001 & 0.1774 & 0.7985 \\ \text { Excretion } & <0.0001 & <0.0001 & <0.0001\end{array}$

${ }^{1}$ The amount of $\mathrm{Ca}$ consumption and excretion were calculated from $\mathrm{Cr}_{2} \mathrm{O}_{3}$ in excreta at each period, as shown in materials and methods section.

a, b, c, d Means in the same row with different superscripts differ significantly $(P<0.05)$.

${ }^{x, y, z}$ Means in the same column with different superscripts differ significantly $(P<0.05)$.

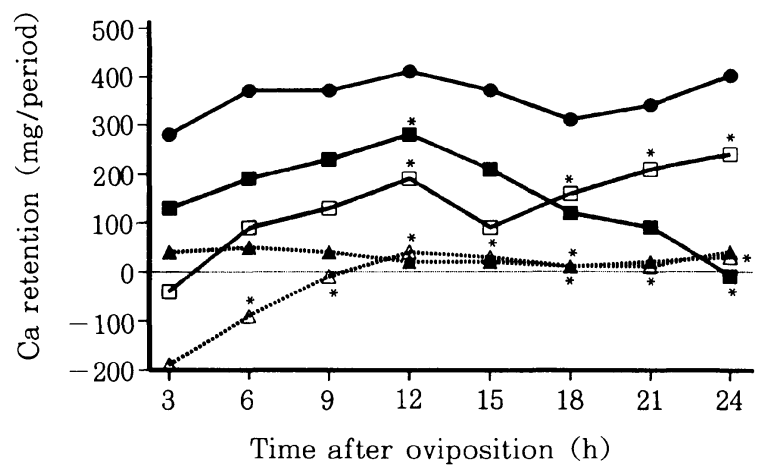

Fig. 2. Time course of retention of $\mathrm{Ca}$ along with egg formation.

Control group ( $\mathrm{SEM}=24.6)$

$1.38 \%$ Ca group 1st day $(\mathrm{SEM}=22.1)-\square-2$ 2nd day $(\mathrm{SEM}=18.8)$

$0.26 \%$ Ca group 1st day $(\mathrm{SEM}=15.1) \cdots \triangle \cdots \cdot 2$ 2nd day $(\mathrm{SEM}=2.9)$

${ }^{*} \mathrm{P}<0.05$ compared to the period between $0-3 \mathrm{~h}$ after oviposition. 
Table 5. Time course of consumption and excretion of phosphorus

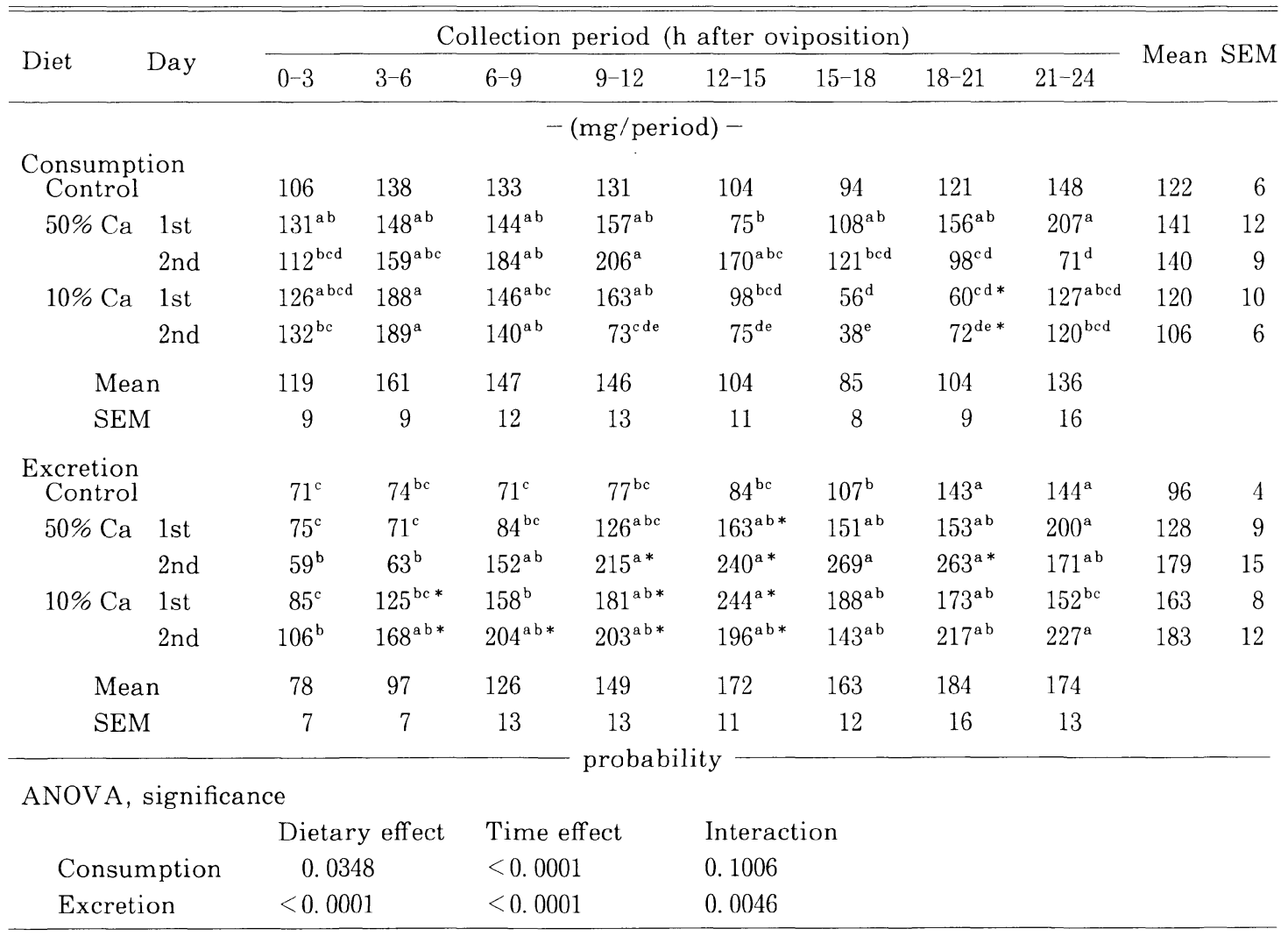

\footnotetext{
${ }^{1}$ The amount of $\mathrm{Ca}$ consumption and excretion were calculated from $\mathrm{Cr}_{2} \mathrm{O}_{3}$ in excreata at each period, as shown in materials and methods section.

a,b,c,d,e Means in the same row with different superscripts differ significantly $(\mathrm{P}<0.05)$.

${ }^{*}$ Means in the same column with asterisks differ significantly against control group $(\mathrm{P}<0.05)$.
}

group.

Fig. 3 shows the fluctuation of $\mathrm{P}$ retention during the egg formation cycle. On the control diet the amount of retained $\mathrm{P}$ decreased during from 12 to $18 \mathrm{~h}$ after oviposition. When hens fed low $\mathrm{Ca}$ diets, it decreased earlier than on the control group.

\section{Discussion}

Even during the dark period when hens consume nothing, the demand for $\mathrm{Ca}$ for shell calcification continues because it takes about $20 \mathrm{~h}$ for complete shell formation. FARMER et al. (1983) reported that the dietary Ca consumed by hens remained in the crops for a few hours after dark and gradually moved into the lower digestive tract until day break. In the present study, the continuous excretion of $\mathrm{Cr}_{2} \mathrm{O}_{3}$ was observed even at night. This is indicated that the food consumed before dark might be maintained in the crop and gradually moved into the lower digestive tract during dark period and also Ca might be kept a continuous supply during shell formation even at 


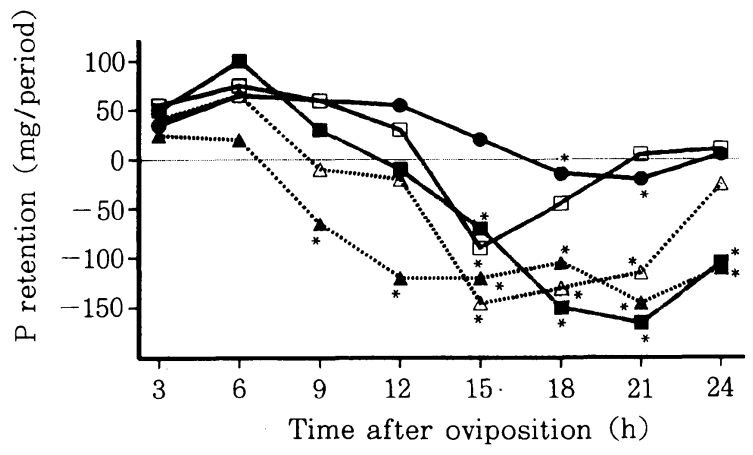

Fig. 3. Time course of retention of $\mathrm{P}$ along with egg formation Control group $(\mathrm{SEM}=6.0)-\mathbf{0}-$ $1.38 \%$ Ca group 1st day $(\mathrm{SEM}=14.2)-\square-$ 2nd day $(\mathrm{SEM}=20.0)-\square-$ ${ }^{*} \mathrm{P}<0.05$ compared to the period between $0-3 \mathrm{~h}$ after oviposition.

night.

It has been reported by many researchers that the rate of shell calcification is not constant throughout the calcification stages (TALBoT and Tyler, 1974; FARMer et al., 1986 ; WATANABE et al., 1992). In another our experiment using the same strain of hens and the same control diet as in the present report, $45.5 \%$ of the shell was deposited during $12-18 \mathrm{~h}$ after oviposition $(9-12 \mathrm{~h}$ before predictive next oviposition time) (WATANABE et al., 1992). As the average shell Ca weight was 2,020 mg, $930 \mathrm{mg}$ of $\mathrm{Ca}$ should be deposited on the shell during this period. But only $680 \mathrm{mg}$ of $\mathrm{Ca}$ was retained as shown in Table 4. Thus, as the Ca for shell calcification exceeds the retained $\mathrm{Ca}$ during 12-18 $\mathrm{h}$ after oviposition, bone $\mathrm{Ca}$ should be mobilized for shell calcification.

Bone mobilization is induced by the parathyroid hormone, which is stimulated by a decrease in the plasma $\mathrm{Ca}^{2+}$ level (SAmmon et al., 1970 ; Sturkie, 1976). Further, the increase in bone mobilization induces a rise in the concentration of plasma Pi released from bone with Ca. WATANABE et al. (1992) showed that the plasma $\mathrm{Ca}^{2+}$ level in laying hen was low during $9-21 \mathrm{~h}$ after oviposition when the shell formation rate was high, and that the plasma $\mathrm{Pi}$ level was high during $12-15 \mathrm{~h}$ after oviposition. Wideman (1987) showed that the exceeded level of plasma Pi was excreted out as endogenous $\mathrm{Pi}$. As shown in Fig. 3, P retention was turned into negative during 15-21 h after oviposition. The amount of $\mathrm{P}$ retention might reflect the fluctuation in the excretion of endogenous $\mathrm{P}$.

On both days after switching from the control diet to the low $\mathrm{Ca}$ diets, the degree of decrease in shell Ca was less than that in consumption of dietary $\mathrm{Ca}$. This is of course because the quantity of bone Ca mobilization increased for a lack of dietary Ca, as shown in the report by FARMER et al. (1986) using ${ }^{45} \mathrm{Ca}$. The fact that $\mathrm{P}$ retention also decreased with feeding lower $\mathrm{Ca}$ diet reflects an increase in the excretion of the endogenous $\mathrm{P}$. Thus, the fluctuation in the amount of $\mathrm{P}$ retained reflects that of bone 
mobilization.

Bone formation was active during pre-calcification (KusUHARA, 1975 ; KusUHARA, 1976). When hens were fed the control diet, $P$ retention kept at a constant level until $12 \mathrm{~h}$ after oviposition, and then began to decrease and kept at the low level until $24 \mathrm{~h}$ after oviposition. Feeding less dietary $\mathrm{Ca}$ resulted in an earlier decrease in the $\mathrm{P}$ retention. But a significant decrease in the retention of $\mathrm{P}$ was not observed during pre-calcification even when hens were fed a diet containing $0.26 \% \mathrm{Ca}$ for two days. Therefore, the contribution of bone Ca for shell Ca might not be so important in the pre-calcification and the early stage of shell calcification. And the amount of shell Ca derived from bone increases with decreasing dietary Ca consumption.

Thus, the present experiments have shown that: 1) as the dietary Ca supply satisfied the demand for shell calcification during early shell formation, bone mobilization might not be active and bone formation might be active; 2) when the rate of shell calcification increased and the demand for $\mathrm{Ca}$ exceeded dietary $\mathrm{Ca}$ consumption, the bone mobilization was activated ; 3) the contribution of bone Ca for shell $\mathrm{Ca}$ changed along with the change of the balance between dietary $\mathrm{Ca}$ intake and the demand for shell Ca.

\section{References}

CHol, J.H., R.D. Miles and R.H. HARMS (1979) The phosphorus excretion pattern and balance during one egg cycle of the laying hens fed a phosphorus deficient diet with or without a single dose of phosphoric acid. Poultry Science, 58 : 1535-1540.

Duncan, D.B. (1955) Multiple range and multiple F tests. Biometrics, $11: 1-42$.

FARMER, M., D.A. Roland, Sr. and J. BRAKe (1983) Calcium metabolism in broiler breeder hens. 1. Calcium status of the digestive tract of broiler breeders throughout a 24-hour period. Poultry Science, 62 : 459-464.

Farmer, M., D.A. Roland, Sr. and A.J. Clark (1986) Influence of dietary calcium on bone utilization. Poultry Science 65 : 337-344.

Hurwitz, S. and A. BAR (1969) Calcium reserves in bones of laying hens: their presence and utilization. Poultry Science, $48:$ 1391-1396.

Ishibashi, T., T. SunAhara and M. YAmASAKi (1986) Time course of distribution of single dose oral or intravenous calcium-45 in laying hens. Japanese Poultry Science, 23 : 75-82.

Ітон, H. (1967) Calcium metabolism in laying hens V. Calcium balance and mobilization of calcium sources for eggshell formation. Japanese Journal of Zootechnical Science, $38: 507-514$.

Kusuhara, S. (1975) Enzymohistochemical studies on the formation and resorption of bones in laying hens. Japanese Journal of Zootechnical Science, 46 : 141-146.

Kusuhara, S. (1976) Histochemical and microradiophysical studies of medullary bones in laying hens. Japanese Journal of Zootechnical Science, 47 : 141-146.

Mueller, W.J., R. Schraer and H. Schraer (1964) Calcium metabolism and skeletal dynamics of laying pullets. Journal of Nutrition, $84: 20-26$.

SAmmon, P.J., R.E. Stacey and F. Bronner (1970) Role of parathyroid hormone in calcium homeostasis and metabolism. American Journal of Physiology, $218: 479-485$.

SAS Institute (1985) SA ${ }^{(R)}$ User's Guide: Statistics, Version 5th ed. SAS Institute, Inc., Cary, NC.

Sturkie, P.D. and W.J. Mueller (1976) Reproduction in the female and egg production. 302-330 in: Avian Physiology. P.D. Sturkie, ed. 3rd eds. Springer-Verlag New York Inc., New York, NY. 
Sunahara, T., A. Annaka, E. Watanabe and T. Ishibashi (1989) Apparent absorption site of calcium and phosporus determined by chromic oxide and polyethylene glycol as markers in the laying hen. Bulletin of the Faculty of Agriculture Niigata University, $41: 29-36$.

TAlbot, C.J. and C. Tyler (1974) A study of the progressive deposition of shell in the shell gland of the domestic hen. British Poultry Science, 15 : 217-224.

Watanabe, E., A. Annaka and T. Ishibashi (1992) Fluctuation in plasma calcium and inorganic phosphorus concentrations during the egg formation cycle. Japanese Poultry Science, $29: 115-126$.

WidEMAN, Jr., R.F. (1987) Renal regulation of avian calcium and phosphorus metabolism. Journal of Nutrition, $117: 808-815$.

\title{
卵殼形成の進行に伴う骨吸収の動態に及ぼす 低 Ca 飼料給与の影響
}

\author{
渡辺恵美子 - 安中昭雄 - 石橋 晃 \\ 新潟大学大学院 自然科学研究科 生命システム科学専攻
}

卵殼形成の進行に伴う骨吸收の動態を明らかにするた めに, カルシゥム $(\mathrm{Ca})$ とリン $(\mathrm{P})$ 排泄量の変動に 対する低 $\mathrm{Ca}$ 飼料給与の影響を検討した。産卵鵎に対 して Ca $2.9 \%$, 有効 P $0.45 \%, M E 2,950 \mathrm{kcal} / \mathrm{kg}$, CP $13.9 \%$ の対照飼料を 7 日間給与した後， 2 群に分け, $1.38 \% \mathrm{Ca}$ 飼料（有効 P $0.48 \%$ ）または $0.26 \% \mathrm{Ca}$ 飼料 （有効 P $0.37 \%$ ）を 2 日閒与えた。対照飼料給与時の最 後の 1 日と低 $\mathrm{Ca}$ 飼料給与後 2 日間の総排泄物を 3 時 閒每に集め, 排泄物中の $\mathrm{Ca}, \mathrm{P}$ 含量の変動を測定した。 また, 経時的な $\mathrm{Ca}$ 上 $\mathrm{P}$ の消費量を求めるため, 内部 標準物質として酸化クロムを飼料に添加した。

酸化クロムの排泄は夜間においても断続的に観察され， 消灯前に摄取された飼料がそのうに留まり, 夜間に徐々 に下部消化管に送られていることが示された。対照飼料 給与時の $\mathrm{Ca}$ 消費量の経時的変動は有意ではなく, $\mathrm{Ca}$ の蓄積量は夜間においても減少しなかった。卵款形成の 後期において P の蓄積量は減少した。この問，P の消
費量は一定であったが，排泄 $\mathrm{P}$ 量が増加したことから， 内因性 P 排泄量が増加したものと考察された。

$1.38 \%$ または $0.26 \% \mathrm{Ca}$ 飼料に切り替えると, 卵款 重とその $\mathrm{Ca}$ 含量は有意に減少し，また， Ca と P の 出納は負の值となった。低 $\mathrm{Ca}$ 飼料給与により, $\mathrm{P}$ 蓄 積量は減少し, また減少し始める時間帯が早期化した。 このことは, 低 Ca 飼料給与により卵款形成中の骨吸 收量が増加し、これが内因性 $\mathrm{P}$ 排泄量の增加をむたら したことを示している。

以上から，卵殼形成における $\mathrm{Ca}$ の需要に対する具 由来 $\mathrm{Ca}$ の供給は, 卵款形成速度によって変動する卵 殼 $\mathrm{Ca}$ の需要と食餌性 $\mathrm{Ca}$ による供給のバランスによ り変動することが示された。

（家禽会誌，29：277-286，1992） キーワード : $\mathrm{P}$ 出納, $\mathrm{Ca}$ 出納, 肖吸収量, 飼料中 $\mathrm{Ca}$ レベル，卵周期 